\title{
De-Westernization and Decolonization in Media Studies
}

Antje Glück, School of Computing and Digital Technologies, Teesside University

https://doi.org/10.1093/acrefore/9780190228613.013.898

Published online: 20 December 2018

\section{Summary}

The need to de-Westernize and decolonize communication and media studies is based on criticisms on a dominant elitist "Western" axiology and epistemology of universal validity, leaving aside indigenous and localized philosophical traditions originating in non-Western settings. Scholars of the Global South continue to question a dominant inherent

Eurocentric bias that was-and continuous to be-underlying many Anglo-American and European research projects. Scholars warn against a persistent influence of foreignimposed concepts such as modernity and development, as well as universal assumptions regarding the use of certain categories and ontologies to deconstruct and understand the media around the globe.

While the West is understood more as a center of power than as a fixed geographical entity, de-Westernization asks for a revision of the power relations in global academic knowledge production and dissemination. The most prominent call for de-Westernizing media studies goes back to Curran and Park who, in the early 2000s, encouraged a Western academic community to revise and re-evaluate their theories, epistemologies, methods, and empirical research approaches, especially in research targeting the Global South.

In a similar way, the call for decolonization asks to investigate and question continuing colonial power imbalances, power dependencies, and colonial legacies. It challenges the uncritical adoption of research epistemologies and methods of former colonial powers in solving local problems, as they fail to explain the complexities of non-Western societies and communities, asking for practicing "decolonial epistemic disobedience." Contrary to de-Westernization aimed at a Western research community, scholars from the Global South have struggled for decades for international recognition of their voices and intellectual contributions to a global academic community. Their ideas draw on postcolonialism, subaltern studies, or a critical-reflective sociology.

Different efforts have been made to address the global imbalance in media studies knowledge generation. However, neither replacing theories with indigenous concepts alone nor being relegated to cases studies that deliver raw data will gain ground in favor of countries of the Global South, as research efforts need to incorporate both local realities and wider contextualization, or the call for a research with a region, not just about or from it. More successful are cooperative South-South efforts, as the thriving scholar networks in Latin America, Africa, or Asia demonstrate.

The de-Westernization and decolonization project is ongoing. Where inequalities appear most pressing are in resource access and allocation, in conference participation, or in publishing opportunities. In this sense, journalism and media studies curricula still reflect largely an Anglophone centrism and a lack of understanding of local issues and 
expectations. Here, more reflective de-Westernizing approaches can help to lessen the gaps. However, as de-Westernization relies on vague geographical categorizations, the term cannot be the final path to re-balance the academic knowledge exchange between powerful and less powerful actors.

Keywords: de-Westernization, decolonization, Eurocentrism, orientalism, Global South, subaltern studies, postcolonialism, journalism, colonialism, communication and critical studies, cultural studies

\section{Why to De-Westernize and Decolonize Media Studies}

The call for a de-Westernization of academic disciplines at the beginning of the 21st century in the West brought a breath of fresh air into social sciences and humanities. De-Westernization describes the criticism of scholars for a predominantly Euro-American ethnocentrism in academic knowledge production. The main argument is the unequal intellectual dominance of the "professional center of gravity in the USA" (Kim, 2009, p. 419) and, to a lesser degree, European academics. As their ideas do not necessarily reflect and apply to current debates and issues in countries of the Global South, critics propose an epistemic shift toward a greater diversity of academic perspectives. Ultimately, this can contribute to a greater inclusivity of fundamental theories, approaches, and concepts worldwide.

Media and communication studies are one of the prime examples for this trend. Despite their inherent openness toward other disciplines, media studies have, since the beginning, been shaped and dominated by US-led problems, ideas, and practices. Arguing with the locality of knowledge, critics point out that US-American approaches cannot necessarily address issues in other parts of the world, where different contexts and epistemologies prevail (Rao, 2011). These non-US-centered approaches need to be taken seriously and analyzed to create a broader knowledge framework. In consequence, "provincializing Europe" (Chakrabarty, 2000) becomes an appeal for a global recognition of previously marginalized voices, for the lessened dominance of Eurocentric ideas, and for the equality of diverse perspectives independently of geography and geopolitics.

Closely interwoven with de-Westernization is the call for decolonization. In a narrow sense, this denotes the process by which former colonies and protectorates achieved their independence and political sovereignty in the last century. However, the formal exit of colonizers and foreign ruling elites does not necessarily entail an abandonment of their institutional and intellectual legacies. Political and economic systems and institutions have been often shaped according to the model of former oppressors; and their ideas continue to influence social and cultural realities. Hence, the process of a genuine decolonization needs to start with "decolonizing the mind" from colonial thinking modalities (Ngũgĩ wa Thiong'o, 1986). This includes a critical revision and reflection about the epistemologies left behind (Mignolo, 2011). 
Both discourses are means to challenge Western hegemony and superiority in defining the core principles of media studies, addressing mainly Western academics in their need to revise their own epistemologies and presumptions. However, while calls for decolonization of global knowledge production mechanisms go back to as early as the 1950s and address both former colonial subjects and rulers, the explicit calls for de-Westernization efforts appear rather recent and are targeting mainly scholars in Western academia in a prerogative manner to deWesternize their work.

This article is divided into two main sections. The first section presents arguments to highlight the broader need to de-Westernize and to decolonize knowledge production and core concepts in media studies. The second section demonstrates the adoption of non-Western and decolonial frameworks to make sense of the media. The article starts with a focus on essential debates on de-Westernization and decolonization of academia with a special focus on media studies. After an outline of how these debates came into being, the epistemological grounds of "Western science" and its power structures, agents, and agenda are highlighted. Here, the main argument is that, though de-Westernization is a good start to think about a more holistic way to integrate varying epistemologies, methodologies, and empirical contributions on equal par, it is also a flawed concept that needs further revision.

After these more theoretical debates, a range of de-Westernization examples illustrates nonWestern thought traditions and empirical applications in different parts of the Global South (Latin America, Asia, Africa, and the Arab world). The final section covers challenges of deWesternization and decolonization, focusing on academic resources and infrastructures, the policy of publishing and citing, and methods. Finally, the conclusion does not limit itself to a summary, but aims to raise points to think about beyond the current status quo.

\section{The Foundations of De-Westernization Discourse}

While academics from countries of the Global South raised the issue of unequal global power structures and, hence, a dismissal of their media and communication scholarship in Western academia for decades with only limited effects, similar calls by Western scholars to Western academics appeared isolated and rather recently. Western hegemonic self-understanding has long taken its theoretical superiority for granted. Golding (1977), one of the first, in his early contribution highlighted how Western journalism ideologies fail to be exported to the Global South. It took a whole decade until Kincaid (1987) provided a groundbreaking study about Eastern and Western perspectives in communication theory, and another decade to Downing (1996), who clearly pointed to the rather exceptional character of the very similar UK and US leitmotifs and data shaping global communication theory, implicitly claiming universality. But it was only in 2000, that Curran and Park's (2000) call for "De-Westernizing Media Studies" reached Western academic solidarity, encouraging curiosity and a broader understanding that "takes account of the experience of countries outside the Anglo-American orbit" (Curran \& Park, 2000, p. 11).

Some factors help to understand how the huge inequalities in global knowledge production and reception developed in the past. They form the base for calls for de-Westernization and are summarized here. 
First, the imbalance in knowledge distribution goes back to past colonial times, when countries of the Global South had little choice but to accept and adapt uncritically to Western epistemologies, models, or curricula in universities and in disciplines such as sociology, anthropology, or later, psychology and economics. This interference of the hegemonic endured even after independence in postcolonial realms.

Second, the long-enduring global Western hegemony caused calls from the South, for deWesternization, to fall on deaf ears in the West in many areas; as US-American and European (white) scholars saw little need to listen. This was first established through the colonial and then bipolar Cold War system, and since 1990, it has clearly dominated through AngloAmerican approaches that retreated from structural and class analysis. Under these conditions, a great deal of Western academic research remained uncritical for a long period of time; assuming modernist ideas of universal relevance. The discipline of media studies, in particular, is a rather young discipline, which was initially shaped by US-American research agendas and paradigms.

These delays in the West took place despite major international attempts to help deWesternizing media efforts, such as the UNESCO-initiated MacBride Commission, gain ground. The MacBride Commission pushed for a New World Information and Communication Order (NWICO) in 1979. In the wake of discussions about cultural imperialism and possibilities of Southern communicative counterflows, communication scholars from Africa, Latin America, or the Indian subcontinent raised criticism on Eurocentric bias and showed an increasing awareness and concern about the decolonization and indigenization of knowledge. It became clear that ideas of de-Westernization were alive, though they did not (yet) have power to impact on Western international communication scholarship noticeably. The "One World, Many Voices" was deeply informed by scholars from the South.

This increasing reflection about the epistemologies of knowledge and the global structures of academic research became visible in discussions about the subaltern on the Indian subcontinent (Ludden, 2002), in Latin American debates and modifications of European theories, or in the founding of cross-national Southern communication associations. But networking initiatives, including South-South conferences, increased knowledge circulation, and a higher awareness among Western scholars could not erase the inequalities around resources, recognition, voice, and knowledge production. The project of de-Westernizing knowledge raised by Curran and Park is still ongoing, as shown by Thussu's (2009) "Internationalizing Media Studies" or Wang's (2011) call for "De-Westernizing Communication Research." Overall, scholars from the Global South continue to struggle for a rearrangement of global knowledge production in media and communication studies.

Nevertheless, some encouraging developments are taking place. First, the gap in recognizing the need to de-Westernize starts to lessen. While parts of the Global South see a legitimate way to develop their own epistemologies, it was decades before a critical mass of Western scholars would accept an academic world outside of their own traditions. This development reflects increasingly in conference organizations and prominent publications in and about the Global South. Second, knowledge generated in and with the Global South gains more importance, functioning as dynamic early warning system for later global developments and newly emerging problems, where traditional (Western) models fail to provide the required 
innovative solutions (Wasserman, 2018). As the 21st century faces the erosion of the traditional understanding of the nation-state, it gives space to present an understanding of the Global South in a different way.

\section{The Foundations of the Decolonization Discourse}

A range of scholars understands de-Westernization at its core as a process of decolonization. History has been closely tied to modernization being imposed during colonial occupation, just as it continues to persist in post-colonial times.

While the term decolonialization appeared around the 1950s, the term decolonality appeared only in the 1990s in the Global South. It describes the partial end of economic coloniality, abandoning the ideology of constant growth and development (Mignolo, 2011).

Decolonization is theoretically closely intertwined with postcolonial theory. As part of postmodernity, it seeks to challenge universal claims of the Enlightenment as a political project. However, decolonial and postcolonial approaches differ. Though they share their origin in broader politics of knowledge production and contest a colonial world order established by European empires, they differ in their geographical origin, time outlook, and theoretical approach. Decolonial scholars stem mainly from South America and address the European incursions on (the later) American territories from the 15th century onward. They link to world-systems theory, and scholars such as Anibal Quijano and María Lugnones have suggested the modernity/coloniality dichotomy (Bhambra, 2014). Postcolonial approaches are embedded in the cultural realm, with South Asian and Middle Eastern diasporic scholars, starting from the 19th century onward, defining the discourse and outlook of European colonialism.

Of analytical and empirical interest are the struggles of competing knowledge systems, and who exercises power over it. For postcolonial scholars, the Martiniquais Frantz Fanon (1952) provided the theoretical entry point with his famous Black Skin, White Masks, a book now famous for its description of how people under colonial oppression became alienated from their sense of self.

Subsequently, postcolonial scholars such as the Stuart Hall, Homi Bhabha, or Gayatri Chakravorty Spivak often incorporated their indigenous or diasporic backgrounds when writing about postcolonial issues, bringing about their own positionality. They have questioned the representation of marginal or subaltern groups, asking for empowering forms of cultural hybridity. In this sense, cultures are not essential entities, but are constantly changing and marked by ongoing negotiations of social realities. Bhabha's proposal of "cultural difference" comprises continuous exchanges leading to new meanings. Spivak follows both neo-Marxist ideas and deconstructive approaches. She sees marginalized (or subaltern) groups as voiceless, hindered in their expression by dominant Western systems of intellectual knowledge reproduction. This is a legacy of colonial times, when non-Western ideas did not become recognized, were deliberately silenced, or were branded as "primitive" by European philosophers and sociologists, exemplified by the attitudes of David Hume or Immanuel Kant toward black African people or by the French sociologist Émile Durkheim calling non-Western people and ideas "primitive" (Connell, 2007; Nwosimiri, 2017). 
Decolonial and postcolonial approaches allow former nation-centered imperial grand narratives to be rewritten into decentered and diasporic ones (Hall, 1997). This helps to challenge not only the rather insular historical narratives of Europe but also endogenous explanations of European origins of modernity and their entanglement with broader histories of colonialism and enslavement. "Can non-Europeans think?" asked the Iranian scholar Dabashi (Dabashi, 2015) provocatively, to pinpoint and deconstruct the core racist ideas of Eurocentrism in the philosophical world of knowledge. .

Decolonial and postcolonial discourses help to understand media structures and media representations in the Global South. De-Westernizing and decolonizing media cannot happen without understanding it as process and context, which is shaped and embedded in history (Wasserman, 2018). Moreover, ahistorical approaches are doomed to fail; and an international diversity of media cases-or as Shome (2016, p. 247) calls it, a "benign apolitical internationalism" is not sufficient. Instead, a more suitable approach appears to be to engage with continuous colonial power relations and the inequalities they perpetuate, while linking media spheres in the West and North with societies in the non-West and South. Decolonization -and in this sense de-Westernization-becomes a "postcolonial interruption of the history of media as universalized and narrated in the West" (Shome, 2016, p. 247); and postcolonial approaches become key to understanding media power relations on a global scale.

\section{De-Westernizing and Decolonizing Epistemologies and Theories}

To better understand the reasons for the call to de-Westernize media studies, the first step is to actually define "the West" - as well as "the rest." The main object of criticism of the deWesternization and decolonization discourses is presented, before moving on to criticism on these debates.

\section{What Is the "West"?}

While many systems of truth appeared and vanished throughout the history of humanity, no human project has been as successful and long-lasting in dominating the globe as the "Western Code" (Mignolo, 2011)—the ascension of "Western" civilization with the beginning of the Enlightenment period, and its embracement as a political project.

However, locating the "West" in knowledge production becomes a slippery road when tied to geo-analytical boundaries. Applying absolute and essential categorizations prove here as unsuitable as they do for the Global South, as the West is not a homogeneous fixed knowledge territory (Waisbord \& Mellado, 2014).

Western geographically denotes generally the "old" industrialized countries of Europe and the "new" English-language states of North America together with Australia and New Zealand. Epistemologically, it is understood as following premises of positivism, rationalism, detachment, self-interest, and individualism, which are closely tied to the invention of Western science. 
If we look at it historically, then a number of countries in Europe are considered the birthplace of modern science, which shapes some of the core evaluative principles of how to perceive, classify, and evaluate knowledge. These countries created the social and intellectual foundations of modern educational systems and academic cultures, which shape today's academic landscape in teaching and research worldwide. Gunaratne (2010, p. 474) declared that the "oligopoly of social science powers" is tied to discipline, language (English), and geography. He considers it to be led by the United States and the United Kingdom, but includes France, Germany, Japan, the Netherlands, and Italy as second tier. This oligopoly reinforces the existing "European universalism."

The Enlightenment marked a break in global history, and it is from then onward that Eurocentrism and later Orientalism (Said, 1978) gained ground as mechanisms for maintaining power over knowledge. Justifications for the Eurocentric narrative consisted in declaring the arrival of (modern) Western civilization into "the arrival of human history" (Mignolo, 2011, p. xiv), with Europe appropriating the reference point of global history as heirs of Hellenistic classical culture; while previous historical epochs were obscured by the invention of a "dark Middle age" past. This worldview came to dominate the initial understanding of the media and its role in society by early US scholars.

\section{How to De-Westernize and Decolonize?}

De-Westernization and decolonization can be understood as ongoing processes. DeWesternization comprises a wide range of meanings. It appears as "act of cultural defense, an anti-imperialist strategy to nurture academic sovereignty, a call for embracing an analytical perspective that reflects a de-centered, dynamic contemporary world" (Waisbord \& Mellado, 2014 , p. 363). The concepts challenge and reposition "the West's dominance (real or imagined) as a conceptual 'force' and representational norm”' (Bâ \& Higbee, 2012, p. 3).

The main criticisms around de-Westernization and decolonization revolve around a dominant elitist "Western" axiology and epistemology of universal validity, leaving aside indigenous and localized philosophical traditions. In the global hierarchy of knowledge they remain underresearched or not taken seriously as a research subject. Theories with origin in the Global South might be dismissed or are critically scrutinized.

Efforts and strategies of de-Westernizing academic disciplines can come from Western and non-Western scholars alike. Ideally, Western scholars strive for a more cross-cultural inclusiveness and incorporation of subaltern perspectives to enrich research and curricula, reflecting and countering potential parochialism and provincialism in their research work. Non-Western academics might seek to position their intellectual work vis-à-vis Eurocentrism, foreign-imposed categories, and ontology. But alternative frameworks and tailored interpretative paradigms in order to understand local social processes (Ray, 2012) is not allaccess to a global academic discourse and finding a voice within this is one of the major issues non-Western scholars struggle to achieve.

A de-Westernization of academia or global knowledge production in general is suggested in all areas of the research process-it encompasses "the subject of study, the body of evidence, theoretical and methodological perspectives, research inquiries, and academic professional cultures" (Waisbord \& Mellado, 2014, p. 363). Special emphasis lies on non-Western cases to 
strengthen conclusions and to guarantee the generalizability of findings and arguments. Having said that, it becomes clear that scholarship needs to move beyond testing USAmerican communication theories in non-Western settings or applying "foreign" categories of particular ontological understandings insensitively.

\section{Why Can De-Westernization and Decolonization Be Criticized?}

As outlined, putting geographical etiquettes on the circulation of ideas might blur knowledge or set wrong dichotomies. In reality, ideas have always circulated. Even in Western societies, views are not monolithic or unanimous, nor are outlooks in non-Western societies. While some might want to shield their culture against the power of globalization (or neoliberal Westernization), others-in particular women or underprivileged groups-appreciate ideas of self-determination. Feminist theoretical approaches reflect this.

In the same way, thinkers who demand an exclusively indigenous or localized scholarship (such as debates around Asian or African values and ethics) seem to ignore the inherently hybrid nature of culture, communication, politics, and society. According to critics, they run the danger of falling into the trap of a new provincialism instead of focusing on what really matters for the Global South: a critique of contemporary power structures that shape the production and flow of knowledge.

That de-Westernization is largely a problem of Western academia, which has timidly attempted to self-critically reflect on it, comes through in the specific character of the debate. For example, an inquiry on Wikipedia, the free, multilingual, and collaboratively written online encyclopedia does not show entries about de-Westernization as a specific term (or its translation into other major languages of the global North and South). ${ }^{1}$ This surprising absence at the time of writing this chapter suggests not only that de-Westernization discourses are led under different names in the Global South (e.g., decolonization), but equally that it remains a topic rather marginalized on Western discursive agendas.

\section{How Does De-Westernization and Decolonization Manifest?}

Understanding the main debates around de-Westernization, decolonization, and their history sets the ground for the second section of this chapter, which illustrates more empirically the current status of global academia in its efforts to de-Westernize and decolonize knowledge.

Examples and a view around important Southern geographies of knowledge production (Latin America, South and East Asia, Africa, and the Arab world) allow mapping the terrain and current status quo.

\section{Practical Examples of De-Westernization and Decolonization}

It appears ubiquitous that scholars in the Global South cannot do research without considering theories of the Northern metropoles-but vice versa, scholars of the North can operate without engaging concepts of Southern origin. However, even within Western places of knowledge production, some metropoles are allowed to ignore others. Two brief examples 
will illustrate how these global hierarchies of knowledge can be better put in context: the first covers the notions of objectivity as a "Western" concept, while the second focuses on the competition of knowledge claims within the West.

First, the Anglo-American concepts of objectivity and detachment are understood to form today one of the basic tenets of modern journalism and, at the same time, serving as an almost universal value for news journalism around the globe. In this sense, objectivity and detachment appear as a central means to investigate what we call truth. However, a closer look on the origins of the concept reveals that these principles go back to the project of Western scientific rationalism of the 19th century, reflecting its dominant epistemology and relying on observations of empirical facts and personal detachment to avoid subjectivity (Harkins \& Lugo-Ocando, 2016). With US journalists quickly adopting it as an ideology, it served and continues to serves as a strategic ritual and a performative act at the same time (Tuchman, 1972).

Southern scholars challenge this Western-inspired epistemology, as neutral seekers of truth actually also control the disciplinary rules, being in a privileged position to evaluate and dictate (Harindranath, 2014). This manifests in the different understandings of truth across space and time. For example, Lenin, the early Soviet Union leader, supported scientific objectivity_but emphasized its capacity to give a structural analysis. Detachment, however, was rejected by Lenin, as he saw media as a good way to educate and mobilize masses (LugoOcando \& Glück, 2018). In a related sense, truth inquiries can be understood as social justice instead of objective facts alone, as pointed out for a more Eastern Buddhist context, where benefits for society gain importance (Martinisi \& Lugo-Ocando, 2015). The idea of social justice echoes in Latin American understandings; while Ubuntu journalism sets ideally on benefits for a community. Finally, a Daoist understanding of media practice regards journalists as facilitators, as sages working for the social good, and hence, embodying a "ziran-wuwei way of life" marked by sensitivity and care instead of a more Western-associated combative or egotistical journalism (Gunaratne, 2005; Loo, 2004).

With the exception of Latin America, where vibrant debates about alternative frameworks have gone on for decades, some of the more recent non-Western concepts and models presented have not yet reached a critical mass of intellectual discursive engagement among Western scholars. Though substantial, they remain rather isolated debates without relevant citations through other scholars (Chakravartty, Kuo, Grubbs, \& McIlwain, 2018).

Second, de-Westernization relates especially to global centers of power rather than to strict geographical dimensions resonates in a reluctance by members of US and UK academia to engage with media scholarship produced in countries considered Western, but not following strictly Anglophone traditions and paradigms. This becomes visible, for instance, in the neglect of a large body of Russian media studies literature, which follows different traditions in academic and journalistic writing, with a focus on an active and more literary authorship instead of a detached-objective stance (Korkonosenko, 2015). In a similar manner, concepts developed by German communication scholars such as the "Onion model" structuring the influence spheres on journalistic news production (Weischenberg, 1992) or Früh and Schönbach's (2005) communication model were little noticed in Anglophone media studies. 


\section{Covering World Regions}

When we speak about knowledge specific to "certain world regions" or "areas"-like Asian or Latin American media and communication studies-what exactly do we mean by this? Does this refer to knowledge produced within an area, or about that area? By "insiders" or "outsiders" of the region, does it mean that knowledge has been produced within a region-or without-and under what conditions set? Finally, what commonalities does a vast geographical territory with coincidental boundary-marking have? The aim to de-Westernize and decolonize academia requires reflecting the scenery first. Scholarship in the Global South can be distinguished according to its inclusion on a global scale and its engagement. Wasserman (2018) outlines three major approaches to media studies: about, from, and with a region. Researching about a region asks whether Africa is treated as "just another" case study for inherently epistemologically biased Northern theory models. This means that models developed for stable democracies are not necessarily applicable in countries of the Global South. Research from Africa engages with a more diverse and inclusive scholarship, supported by the rise of mobile and online communication and counterflows from actors such as $\mathrm{Al}$ Jazeera. However, not each voice from Africa might be innovative. Hence, Wasserman sees the best option in research with Africa, where global problems play out early in localities-ahead of Western countries-providing an early warning system for future problems of the North.

\section{Latin America: Practice and Activism}

Latin America achieved independence from colonialism relatively early-by the mid-19th century, almost all Spanish colonies had become independent, though different forms of interventions and postcolonialisms persist. The early removal of colonial ties allowed scholars to engage with a plurality of European and other perspectives, with intellectual independence, and to form their own and hybrid ways of thinking.

A critical mass of thinkers have shaped a distinct manner of Latin American knowledge about media, which can be roughly characterized by its syncretism due to its global rather peripheral position, and by its interlinking of scholarship with practice and activism (Enghel \& Becerra, 2018). This translates into a distinct writing style, which involves scholars being conscious about their status as political subjects-something that does not always go along with established journal publications from the global North. Some the most prominent representatives of Latin American discourses are Antonio Pasquali, Paulo Freire, Rosa María Alfaro, Jesús Martín-Barbero, or Luis Ramiro Beltrán, to name but a few. The Brazilian Paulo Freire proposed a philosophy of critical consciousness, which sees the value in local knowledge and active participation of people, questioning and resisting (neo)colonial assumptions and discourses (Ullah, 2014). Alfaro contributed to issues of communication in the communal perspective and to issues of gender and feminism from a Global South perspective. Martín-Barbero suggested the mediation concept, understanding audiences to be active participants in the communication process long before Western scholars developed similar ideas; and the Bolivian Beltrán proposed a democratization of communication, foreclosing later debates about breaking the dominance of communication flows from the global North. 
Despite having been shaped by a strong mutual exchange with Europe and the United States, reaching back to the 1950s, some specific indigenous concepts found recognition. For instance, Tawantinsuyu ("realm of the four parts"), developed by Aymara and Quechua Inca thinkers, relies on core principles of communalism and reciprocity, and represents an alternative to democracy or socialism (Mignolo in interview with Mattison, 2012).

However, for a long time, and despite a long engagement with decolonizing and deWesternizing ideas, Latin American communication scholarship led a niche-existence amid global media studies; its rich literature output in Spanish and Portuguese was marginalized by US scholarship through language barriers. It was only in 2018 that the widely read Communication Theory, journal of the International Communication Association, incorporated a special issue about Latin America centering on its media theory.

\section{South Asia: Subaltern Studies}

Having been part of the British Empire for roughly 200 years as a colony, India, Pakistan, and Sri Lanka (and later Bangladesh) gained independence from the British Crown in 1947/1948. As the time under the British Raj had been highly violent, exploitative, and backed by a strong nationalist movement, calls for decolonization efforts quickly gained prominence. DeWesternization appeared first and foremost as decolonization. But this has not been a simple endeavor, as colonial structures have persisted in the political system, in higher education, and the media. The same applies to knowledge routines.

This legacy generated two prominent interlinked critical de-Westernization currents on the subcontinent. These are the Subaltern Studies, which are part of postcolonial studies.

Founded by a circle of mainly Indian academics in England, at the end of the 1970s, the field of Subaltern Studies originally described movements "from below" or "from the bottom upward." Subalterns signified nonelites who were considered agents of political and social change. It was influenced strongly by Marxist and Gramscian approaches and considered itself at the forefront in the struggle for political and cultural decolonization, first in India and later in Latin America, giving an authentic voice to those excluded from power (Turner, 1994). Subaltern Studies found inspiration in the works of Erik Stokes and Ranajit Guha.

With time, its focus shifted. Where originally subaltern approaches looked at peasants as main subaltern groups, class struggles and insurgencies, or modernity and its relation to colonial India, the interest changed toward discursive constructions of culture, knowledge, and power to overcome colonial narratives of the nation and to establish a stream of "postcolonial critique of modern, European, and Enlightenment epistemologies" (Ludden, 2002, p. 20). This strategy of "provincialising Europe" (Chakrabarty, 2000) draws on the struggle to establish alternative narratives. Among them are "Asian spiritualism," proposed by Bengali poet Tagore; non-modern social knowledge (Arjomand, 2008; Connell, 2007); and an indigenous Vedicbased holistic communication theory (Sadharanikaran model of communication, emphasizing oneness and successful communication; Adhikary, 2014) to explain contemporary popular Indian cinema in the face of Western misinterpretations (Murthy, 2012), or-more doubtful, though-to explain popular pseudo-science discourses about the Vedas led by Hindu rightwing forces. 
Journalism research has identified different role conceptions for Indian journalists. Away from being detached, Indian journalists understand themselves to be more politically involved, as social reformers, political analysts, or environmental advocates (Ullah, 2014).

Although South Asian philosophy provides a richness of ancient ideas stemming from Hinduism and Buddhism, only a few of these ideas have been explored as to whether they remain valid for explaining the present. India's philosophical heritage was to a large extent shaped by the Vedas and Upanishads, or by the Ramayana and the Bhagavadgita. These scripts are kept in Sanskrit and form the religious body of Hinduism. They talk about the concepts of Samsāra (cycle of rebirth), dharma as the ethical guiding principle of the right path, and, more recently, ahimsa (compassion, also nonviolent resistance; Gunaratne, 2009a). This legacy contributes to popular national Indian narratives.

\section{East and Southeast Asia: Interconnectedness, Uchi/Soto Development Communication}

East and Southeast Asia-a large region that comprises theory approaches and epistemologies incorporating ideas generated between China and the Philippines-provides rich, fertile ground for ontological and epistemological concepts that differ from Western ideas. Among these Asian systems of thinking are Buddhism and Daoism, or Japanese approaches.

The production of knowledge in communication studies can be achieved by inquiring into traditional Asian ideas about human communication and by critically examining Europeanimported approaches (Dissanayake, 2009).

Efforts to integrate traditional Asian ideas were made by a variety of scholars. Gunaratne proposes his own approach to communication outlets and free expression. He draws on Daoism (Gunaratne, 2005), suggesting complex dynamical systems theory, cybernetics, and complexity science as a "natural arena of axial Asian philosophies" (Gunaratne, 2010, p. 483). Besides this, principles of Buddhism can serve to describe global developments in communication by relating them to life-cycles of the Buddhist wheel of becoming (bhavacakra; Gunaratne, 2015). In addition, Gunaratne (2014) suggests how journalism can be practiced following Buddhist principles of the paticca samuppada (theory of mutual causation or dependent co-arising). This Buddhist (and similarly Daoist/Hindu) ontocosmology of interconnectedness challenges Western thinking, as it casts doubt on the NewtonianCartesian paradigm.

Other approaches are Lo's (2013) "Asia as a method," meaning the soft resistance against Eurocentric ideas by exploring them and developing them further; Kuo and Chew's (2009) culture-centric approach, which aims to form a distinct but open cultural perspective; or contributions of Combs (2005), and Dissanayake (2007), in Buddhism and Laozism. In an effort to critically reflect Western knowledge, Faust (2017) put the Yin Yang principle in communication in perspective with the German Dynamic Transactional Approach. These efforts to relate knowledge of different thought traditions to each other are so far sparse, but seem productive in a sense to de-Westernize knowledge more profoundly. 
Japan has shown a remarkable set of its own concepts. Ishii's enryo-sasshi communication relates to the sender's silence and ambiguity, while the receiver shows sensitivity. The Buddhist Bodhi (or path to enlightenment) could be considered as ultimate communication, while kuuki denounces an atmosphere requiring compliance and producing social consensus (Gunaratne, 2010). The uchi/soto distinction (interior, us vs. exterior, them) describes the "belonging of people to social groups linked by close interpersonal relationships" (Takahashi, 2007, p. 6). In digital times, multiple uchi belonging are ubiquitous.

Perhaps one of the most important non-Western contributions, however, was the Southeast Asian school of development communication. Based on Quebral's (1975) landmark paper "Development Communication in the Agricultural Context," in the early 1970s, Development Communication became institutionalized at the University of the Philippines in Los Baños (UPLB) and is a field important to many countries of the Global South.

\section{Africa: Ubuntuism, Afriethics, Oramedia}

Talking about Africa as an entire continent suggests a homogeneous entity. But this is not the case. More than any other continent, Africa is characterized by its extreme diversity in languages, beliefs, ways of living, and traditions. And the continent falls apart in Westernorigin classifications-while "Africa" usually denotes sub-Saharan regions, Africa's Arabic- and Berber-speaking north is geopolitically subsumed as part of the Middle East and North Africa (MENA) region.

What unites many African countries is the century-long history of colonialism and the slave trade, and Eurocentric stereotyping as the Dark Continent. Its reduction to media images of hunger, failed states, poverty, corruption, and backwardness has dominated television screens for decades. The struggle between Westernization and African traditions is on-going in many areas; and new, powerful non-Western actors like China have entered the stage, shaping local African media agendas (Madrid-Morales \& Wasserman, 2018).

When looking at media research, scholars conclude that overall external (and especially Western) research paradigms continue to strongly influence and dominate scholarships in African countries, with a distinct African perspective still to emerge (Ndlela, 2009). With the increase of African media scholars and publication efforts, the diversity, hybridity, connectedness, and challenges of the African media studies landscape have gained more international visibility-see the recent examples by Mutsvairo (2018), and Mutsvairo and Karam (2018). Many topics remain under-explored-for instance, the growth of Internet and mobile telephony, African online cultures and big data, or the media usage by social movements (Bosch, 2018).

On the theoretical, deontological, and empirical side, three theoretical approaches play an important part in a de-Westernized, decolonized understanding of media research in the African context: Ubuntuism, the closely interlinked Afriethics debate, and oramedia.

Ubuntuism is a philosophy that "values humanness, dialogue, the public good, consensus, and community care" (Fourie, 2007, p. 25). The term originates in the South African Bantu languages and means humanity. Compassion, cooperation, and collective responsibility characterize the Ubuntu idea, which is believed to provide a common thread in beliefs, 
customs, value systems, and socio-political institutions of societies in sub-Saharan Africa. Ubuntu emphasizes relationships between people and rejects notions of solitary humans. It is shaped by principles of care and interdependence, while maintaining an inclusive character that helps to create a pan-African unity. For African countries, Ubuntu facilitates intellectual decolonizing efforts and the break with colonial and apartheid pasts.

Ubuntuism connects to ideas of Afriethics, a normative framework proposed by the Zambian Kasoma who proposes a normative "African cultural exceptionalism," urging media professionals to center less on money and power and more on society, morally respecting the bonds of community life (Banda, 2009). This links to Etzioni's (2003) moralistic communitarian ethic. Criticism revolves around Kasoma's absolutist and essentialist views of African society, his neglect of the hybridity of African identities shaped by historical interlinkages with other peoples through trade or colonialism, and his reaffirmation of simplistic North-South dualisms. Local journalistic practice in Africa happens in creolized environments today.

Finally, oramedia describes distinct media practices rooted in many African countries. The importance of traditional folk media as a means of communication to mass (community) audiences was highlighted by Ugboajah (1982), relying on town criers, storytellers, talking drums, or visual symbols and colors to diffuse knowledge within a village setting.

Looking at the field of journalism, it can be asked if an understanding of African society as determined by Ubuntu, cooperative and deliberative values, and consensual democracy (Wiredu, 2001), might require in consequence a different-non-Western-kind of journalism. What role models might be adequate for African countries? Skjerdal (2012) suggests three major streams of journalism deployed in Africa, which differ essentially from Western libertarian ideas in their interventionist and essentialist self-understanding. These streams range from communal journalism serving foremost the needs of the local community (based on Ubuntu and Afriethics), to journalism for social change (with journalists as interventionist change agents, activists, or advocates), to journalism inspired by oral discourse retaking the rich narrative traditions of Africa. African journalists maintain a distinctive local identity while understanding themselves as connected to more universal professional values, acting as watchdogs toward power abuse or the marginalization of dissenting voices.

\section{Arabic World}

The Arab world also was, for long time, under colonial occupation or mandate rule. Contrary to other continents, its mostly Islamic identity helped to keep foreign rulers at distance. Contrary to the West, in most Islamic states the secular sphere did not separate from the religious sphere. As mentioned, Frantz Fanon and the anticolonialization movement in Algeria were one of the early drives in generating an understanding about oppressed identities.

The Arab-Islamic (as well as Arab-Jewish and Arab-Christian) heritage was for centuries a rich source of knowledge in medicine, astronomy, agriculture, philosophy, or sociology (Masood, 2017). Through extensive translation activities, Arab scholars formed the major bridge to the knowledge legacy of the Classic Greeks, refining and developing their ideas further. As Western modernity narratives relegated the time before the Enlightenment to the "dark ages," the immense contribution of the Arab-Islamic heritage to modern science became subsequently forgotten. 
The most prominent among the narrative knowledge reconstruction efforts was what the Palestinian-born Edward Said (1978) coined Orientalism. In this famous book, Said analyzes the discursive dimensions of British and French colonialism in the 19th century. ${ }^{2}$ Orientalism understood the Western construction of knowledge about how to understand Islam and the Middle East (or Asia) as one instrument for maintaining hegemony and power during colonial imperialism and colonialism. In its core, Orientalism draws on fundamental differences in representing the Occident and the Orient, where Western or Judeo-Christian concepts (of individualism, rationality, libertarian democracy, or a free press) were seen to be superior to Eastern cultures or concepts, such as the Buddhist idea of no-self, middle-path democracy, or the unity between individuals and the cosmos (Gunaratne, 2005, 2009b). This discursive construction of the Other made power relationships visible, through stereotypes of the unpredictable, sensual, exotic, erotic, and strange Orient versus a rational, energetic West, emphasizing personal autonomy and individualism. With Africa, a whole continent was equated with traditional thinking and superstition (Kassab, 2013, p. 327). "To know is to subordinate" (Turner, 1994, p. 21) was understood as being in a position of power to define who and what is the Orient. Edward Said saw Orientalism acting as a "Western style for dominating, restructuring, and having authority over the Orient" (Turner, 1994, p. 3).

Orientalism showed that science and its written history are not automatically neutral. In consequence of the Orientalist criticism, Occidentalism emerged as a countermovement, dismissing "everything to do with the West and an implicit rejection of the legacy of modernization” (Turner, 1994, p. 7).

The construction of the "Orient" and "Occident" is an imaginative geography. This reflects the failure of demarking geographical boundaries, with borderlines set by (arbitrary) human decision-making, not by facts. The "West" becomes a geocultural or a geopolitical framework with politically motivated, subjective designations of symbolic geography (Bâ \& Higbee, 2012).

The colonial era left its traces in the Arab world. Political divisions, a focus on natural sciences instead of humanities, and a long history of deploying Western concepts in communication research require efforts to critically rehistoricize Arab media studies (Dajani, 2013; Jayyusi, 2007). In today's Arab world, several attempts have been made to apply Islamic knowledge frameworks to different fields in the media. Among them are an ethical framework for journalism practice from an Islamic point of view (Mohamed, 2006) and a look at a model of Islamic communication by Hamid Mowlana (2007), who emphasizes Tabligh (social communication, propagation) in a largely Iranian context. But his communication model was criticized for its homogeneously assumed belief and religious practice, ignoring the complexities of different Muslim communities and neglecting existing power structures (Semati, 2011).

After having outlined four major areas and their concepts and strategies of de-Westernization and decolonization, the focus turns now to more general systemic deficits in global academia. 


\section{Symptoms and Structures of Global Inequalities in the Academic System(s)}

It is not hard to make out the main points of how imbalances erupt in global academia. Some factors are visible on first sight; others can be understood through a more structuralanalytical approach. The following sections highlight the two main areas of inequalities: the general set-up and structure of the academic system (and who defines what is "general") and the methodological approaches as well as empirical practices in research about the Global South.

\section{Status Quo: General Academic Infrastructures}

The enormous global differences in academic knowledge production can be explained, to a large extent, by the existing inequalities in relation to access to resources and channels of distribution and circulation of knowledge. These comprise the resources and practices available to academics in their professional work.

Academic cultures can be understood as a "network of interrelated and explicit beliefs about the academic practices of teaching, learning, and research" (Ringer, 1992, p. 13). These practices and rules of academic performance are learned through training that follows specific academic models, and are reestablished through specific practices, among them conferences, peer-reviewed journal publications, or research grants (Lamont, 2009). As economic inequalities and predefined evaluation models impact this considerably, Waisbord and Mellado (2014) ask rightly if the globalization of communication studies might carry a "distinctive 'Western' accent."

This is reflected, for example, in journalism education, where Anglo-American/Western approaches keep on setting the tone (Deuze, 2006; Goodman, 2017a). So far, even the proposed UNESCO curriculum for journalism does not include a focus on regional adaptions. Hence, a de-Westernization or decolonization of journalism curricula seems overdue. It can be rightly asked if US news reporting practices, with their emphasis on objectivity and detachment, are adequate to reflect realities in countries as diverse as India, Kenya, or China. Local realities and contexts shape news journalism considerably (Rao, 2011), and it can be asked if an engaging journalism relying on (a certain dose of) emotions and empathy, instead of detachment, might be a more functional strategy in a country like India, where many institutions fail to serve its citizens (Glück, 2016). Equally, unreflected Western provincialism fails to explain ground realities in transitional democratic systems such as South Africa, shaped by a legacy of colonialism and apartheid (Dube \& Rabe, 2017).

Besides, the academic infrastructure is shaped by how media studies as a discipline is understood-should it be an independent discipline, or can it better be integrated into area studies? While some see its subject-specific competence in regional knowledge and language resources as a strength and advantage for de-Westernizing efforts (Jaber \& Richter, 2014), others hint at the difficulty of subsuming media research within area studies, where each branch focuses only on media phenomena of a distinctive geographical space. This is problematic because of the understanding of area studies as a deeply Western construction of world geopolitics (South Africa and Ghana both belong to "African Studies"-but how much do 
they actually have in common?): its compartmentalized analytical categories; its establishment of an artificial othering dichotomy-"non-West" versus "West"; and its disconnect from broader discipline-specific meta-discourses and issues (Waisbord, 2015). Against this academic insularity and balkanization of scholarship stands the call for more cosmopolitan media studies open to multiple perspectives (Waisbord, 2015).

In two areas of academic infrastructure global inequalities become most visible: access to physical and social resources and publishing.

\section{Access to Resources and Networks}

The de-Westernization of media and communication studies will remain incomplete unless it starts to recognize the structures of power and resources that determine the hierarchy of knowledge in the academic world.

Research institutions shaped according to Western models might rely on scholars educated in Eurocentric thinking traditions. Though today, it would appear naïve to assume that Westerntrained scholars apply learned Western approaches unreflectively, it is not uncommon that midrange theories or culturallyspecific concepts or methods are considered as superior Western knowledge (Gunaratne, 2009a). This import of Western frameworks might enhance career and publication opportunities. Novel ideas run the danger of appearing quite isolated in a Western-dominated academic discursive environment; and case studies from the South might well test Western-generated theory models in non-Western setting.

In terms of resources, universities face huge technical inequalities. Be it office space, hardware, or software-some research institutions in the Global South struggle for access to "sophisticated quantitative tools their Northern colleagues take for granted" (Ray, 2012, p. 245). Taking the widely used statistics software SPSS as case, how can a sound quantitative data analysis be generated if access to SPSS is restricted to institutions that can afford an expensive license?

Next, scholars from countries of the Global South face huge limitations in terms of knowledge dissemination and distribution for reasons of language and access to funding. It is obvious that comparatively few participants from the Global South attend big media studies conferences such as by the International Communication Association, or International Association for Media and Communication Research. Despite a willingness to present their work to an international audience, scholars from the Global South face difficulties in access to funding for conference travel and accommodation costs-even reduced participation fees often remain too high. In some countries, salaries in academia might be so low that scholars have to supplement their income by other means-for instance, driving a taxi.

Another relevant issue is the barrier of language-how many academics worldwide speak English well enough to present or to publish in high-ranking journals? It was a very significant moment in the 2017 IAMCR conference in Cartagena (Colombia), when the British London School of Economics media professor Nick Couldry delivered his keynote talk in Spanish, confessing later to have learned it in order to read the works of Latin American scholars such as Martín-Bambero in the original. 
With regard to fundamental research networks, some regions did well in institutionalizing South-South or regional cooperation, others did not. Two major inter-Latin American communication research associations were founded after the MacBride report-the Asociación Latinoamericana de Investigadores de la Comunicación (ALAIC, in 1978, in Venezuela) and the Federación Latinoamericana de Facultades de Comunicación Social (FELAFACS, in 1981, through the help of the German Konrad Adenauer Foundation), and Africa too saw an early emergence of a network of scholars-the African Council for Communication Education (ACCE, founded in 1974), based in Kenya. However, Arab countries -despite sharing a common language-saw their first inter-Arab communication researcher association coming up only in 2013, when the Arab-European Association for Media and Communication Researchers (AREACORE) was founded-in Germany. ${ }^{3}$ Earlier efforts had failed due to different colonial heritages in the MENA (Middle East and North Africa) region, and subsequently, a lack of a coherent linguistic terminology (Hammami, 2005). AREACORE's members from around the Mediterranean Sea share a research interest in Arab media and a cross-cultural dialogue (Jaber \& Richter, 2014).

Furthermore, the political system exercises a considerable influence on ideology and practice of academic work. With some countries regarding social sciences and media studies as sensitive disciplines for national integration and security, certain forms of control or subtle limitations on access for foreign funding are highly likely to be in place, making international cooperation and transnational research projects difficult (Jaber \& Richter, 2014).

\section{Publishing and the Politics of Citing}

Publishing in the "good journals" that are conducive to higher levels of citations by other researchers are the international trademarks of academic success. Not only does this affect the self-esteem of researchers, but in many places colleagues, grant-giving institutions, or higher education administrators take citation counts as a key measure to evaluate the recognition and importance of an academic. Peer-reviewed (English-language) publications and journals decide promotions, awards, and grants. Hence, it is no surprise that in this system quantitative numbering and counting outweigh the quality of the publications (or their niche locations), and that rituals of quantification suggest an objectivity that is not actually present in this strictly institutionalized academic practice.

Addressing this politics of citing in Cultural Studies, Chakravartty et al. (2018) found a significant underrepresentation and marginalization of non-Western scholars, scholars of color, and females in US-American journals (Chakravartty et al., 2018). With non-Western scholars virtually absent until 1990, their share has continued to be underrepresented even 20 years later, with only $12 \%$-and with a specific focus on race-related topics. However, despite increased visibility, works by nonwhite scholars are cited significantly fewer times.

Though relevant citation indexes for media studies such as the SSCI claim to cover "the world's top tier international and regional journals," they have been criticized as resembling a black box (Klein \& Chiang, 2004). An English journal version is mandatory, and the majority of journal publishers are based in Anglophone countries. At present, the SSCI considers only two peripheral communication journals (Asian Journal of Communication and the Chinese Journal of Communication) - both are published in the United Kingdom, and their editors are based in Asian centers of power-Singapore and Hong Kong. This means by and large that "Southern 
researchers have to follow the guidelines set by their Western counterparts to publish in international journals, often required for tenure, promotion, or to secure funding," and often shaped by a dominance of the metropoles (Bosch, 2018, p. 421).

However, in 2015, the Emerging Sources Citation Index (ESCI) was introduced. This might be a first step to de-Westernization and decolonization, comprising at present (June 2018) 104 communication-related journals-a fifth from non-Western countries and seven from eastern Europe/Russia. But with no impact factor, these journals remain relegated to a minor role, while some important journals are entirely absent (e.g., two-decades-old Arab Media and Society, published by the American University in Cairo does not belong to these indexes).

In the face of this evidence of interwoven academic structures and access imbalances, the allegation that Western publishers practice "academic imperialism" (Gunaratne, 2010, p. 489) can appear quite realistic.

\section{Status Quo: Methods and Empirical Research}

The structural bias continues when looking closer at research designs and empirical investigations. First of all, the nation as a standard unit and framework for media research still dominates. However, this methodological nationalism fails to consider an increasing global interconnectivity and transnational flow of communication activities.

Second, major cross-national research projects such as World of Journalism, MeCoDEM, or INFOCORE, show efforts to provide comparative settings and explicitly include actors of the Global South. ${ }^{4}$ But this ambition can be difficult, as becomes obvious in the World of Journalism project. Asking journalists in 67 countries through a standardized survey about role perceptions, working conditions, and the value of various professional principles in news work, the quantitative data collected at times can only superficially reflect the complexities of situations on the ground. This concerns principles such as objectivity, autonomy, or detachment, which might be upheld in many countries, but very differently understood or implemented. Some concepts cannot be translated at all.

As a last point, unequal research infrastructures shape the everyday practice of research. For example, quality audience research is difficult in countries where only economic pressures force audience research institutions to support largely applied or profit-oriented market research (Desai, 2017). More curious is the criticism pointing to a systematic sample bias of empirical studies in psychology and media effects. With the bulk of the studies being done in US research universities, study participants are usually recruited from "white, upper-middle class, Christian, American young adults” (Levine, Park, \& Kim, 2007, p. 206)—mostly undergraduate students in exchange for credits.

\section{Beyond De-Western and Decolonial Discourses: A Conclusion}

This chapter has outlined how calls for de-Westernization and decolonization have influenced approaches toward media studies. However, as has become clear, de-Westernizing is a pending and incomplete project in media studies. Indeed, scholarly approaches, models, and theories from the West still define the paradigms for many researchers. Hence, they translate 
into methodologies, empirical research strategies, and theoretical concepts that continue to shape our own knowledge and understanding of the media in general. The Global South continues to be analyzed through the eyes, experiences, and values of the North, while those from the Global South and their own stories continue to be ignored and rendered invisible.

This lack of awareness is not deliberate but is instead a manifestation of structures of academic power, which tend to reflect concentration of resources and centralization of mechanisms for dissemination of knowledge. Few, very few, academics in the Global South can access the international academic conferences or have the time and resources to perform empirical research on the same scale as their Northern counterparts. Even fewer have access -or commercial ability to sustain-those journals that are part of the Western-dominated system of indexation, which sets the tone for any knowledge paradigm in this realm. It is important, therefore, to recognize a series of key aspects of this project.

1. De-Westernization as a concept remains problematic when, instead of focusing truly on intellectual engagement, it draws on a dichotomic opposition that relies on geographical boundaries. These boundaries are insufficient as a denominator for the diffusion of ideas. As Mignolo remarked: "The point, however, is not where you reside but where you $d$ well" (Mignolo, 2011, p. xiii). Putting an opposition between geographical entities such as the Global South and the West/North deludes a complex set of idea generations characterized by interlinkages and hybridity, and a transnational and cosmopolitan character. Apart from that, the South is not the only neglected sphere. Just as the West has never been a homogeneous entity, a de-Westernization and decolonization process needs to incorporate knowledge traditions and indigenous concepts of noncolonial powers, and also to direct the focus onto the historic "Second World" (the Eastern Bloc during the Cold War). Even though these areas belong nominally to the Western sphere, they have found limited consideration in Westerndominated global academic discourses.

2. Building on this argument is the focus on power. If ontologies and epistemologies around the globe are truly to be understood, breaking notions of intellectual core and periphery, the focus on power relations can be only one among many. Within media studies, actors and nations perceived to be powerful have always been under close scrutiny-first, research interests were directed to selected countries of the West and North; now, this has been extended by newly emerging economies such as China, India, or South Africa. However, it is not a solution to look only at the powerful as it runs the danger of repeating previous mistakes-to set the focus on the politically and economically powerful, while neglecting the poor. Focusing on the powerful is a structuring mechanism of reality, but it obscures other, less powerful actors.

3. Structural inequalities and imbalances in academic media studies can be overcome by setting priorities on both analytical and practical measures. Though the disparities in academic infrastructures cannot be overhauled overnight, a change can be initiated in the modalities of treating knowledge originating in the Global South. This means moving away from regarding non-Western settings as colorful case studies that only confirm (more or less well) Western theories and concepts. Instead, these should be replaced by a more inclusive approach, a "cosmopolitan sensibility to avoid the geocultural limitations of knowledge" (Waisbord, 2015, p. 368) aiming for truly universal world knowledge, and continuing in the traditions of global knowledge 
exchange, as has been the case for centuries between Asia, the Islamic world, and Europe. Of further help against the imbalances in knowledge production is an integration of de-Western and decolonial perspectives into media studies and journalism curricula, and-as is the case in journalism education-an increased contact with each other-through student exchanges and the creation of a community of scholars across borders, supported by the UN Educational, Scientific, and Cultural Organization (UNESCO) and the World Journalism Education Council (WJEC).

All in all, it can be argued that de-Westernization should matter more to those in the North than those in the South. It is fundamentally a problem for scholars in the West, who not only hold power, but who claim to be deconstructing the media world in a critical manner. As Thomas Kuhn (1962) wrote, the advances in science and human knowledge have occurred when there has been a fundamental shift in the paradigms of science. It is Western scholars, who operate within the boundaries set by their own paradigms, who are called not only to challenge self-perceived universal assumptions but also to contest globalized paradigms so as to allow them to truly advance knowledge by bringing other distinctive epistemologies into the discussion. As long as scholars in the North do not incorporate these other epistemologies and accept that decolonizing the mind is not just a task for those in the South, our understanding of the media will remain flawed, incomplete, and Western-centric. This is why it is such an urgent endeavor to accomplish.

\section{Links to Digital Materials}

A more general outlook on ideas of de-Westernization and decolonization are given by these sources:

The Alternative Reading List Project <https://thealternativereadinglistproject.wordpress.com/ $>$. What voices aren't you hearing?

Discover Society: Measured - Factual - Critical <https://discoversociety.org/ $>$.

Global Social Theory <https://globalsocialtheory.org $>$.

Resources that generally deploy a de-Westernizing and decolonizing approach:

Global Dialogue $\leq$ http://globaldialogue.isa-sociology.org/ $>$. Magazine of the International Sociological Association.

Information Geographies <http://geography.oii.ox.ac.uk/about/>. Mapping Geographies of Knowledge.

Southern Perspectives $\leq$ https://www.southernperspectives.net/>. A Lateral Dialogue of Ideas. Resource with a clear focus on de-Westernization in media studies:

Global Media Journal <http://globalmediajournal.de/en/home/>. German Edition.

\section{Further Reading}

Beltrán, L. R. (2014). Comunicología de la liberación, desarrollismo y políticas públicas: Viladamat, Spain: Luces De Gálibo. 
Glück, A. (2015). De-Westernisation: Key concept paper_http://eprints.whiterose.ac.uk/ 117297/1/Glueck\%202016 De-Westernisation.pdf>. Working Papers in the MeCoDEM. Leeds, UK: University of Leeds.

Nandy, A. (1983). The intimate enemy: Loss and recovery of self under colonialism. Delhi, India: Oxford University Press.

Ngomba, T. (2012). Circumnavigating de-Westernisation: Theoretical reflexivities in researching political communication in Africa <https://dx.doi.org/10.1080/02500167.2012.717346>.

Communicatio, 38(2), 164-180.

\section{References}

Adhikary, N. M. (2014). Re-orientation, ferment and prospects of communication theory in South Asia. China Media Research, 10(2), 24-28.

Arjomand, S. A. (2008). Southern theory: An Illusion Raewyn Connell<https://dx.doi.org/ 10.1017/S0003975609000356>, Southern Theory. The Global Dynamics of Knowledge in Social Science. Cambridge, UK: Polity Press, 2007. [Book review] European Journal of Sociology/ Archives Européennes de Sociologie, 49(3), 546-549.

Bâ, S. M., \& Higbee, W. (2012). Introduction: De-westernizing film studies. In S. M. Bâ \& W. Higbee (Eds.), De-westernizing film studies (pp. 1-15). New York, NY: Routledge.

Banda, F. (2009). Kasoma's Afriethics: A reappraisal_<https://dx.doi.org/ 10.1177/1748048509102179>. International Communication Gazette, 71(4), 227-242.

Bhambra, G. K. (2014). Postcolonial and decolonial dialogues_<https://dx.doi.org/

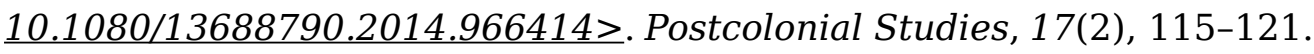

Bosch, T. (2018). Rethinking media research in Africa. In B. Mutsvairo (Ed.), The Palgrave handbook of media and communication research in Africa (pp. 413-426). Cham, Switzerland: Palgrave Macmillan.

Brown, K. (2013). Asian and African values: The problem of human rights <http:// www.polity.org.za/article/asian-and-african-values-the-problem-of-human-rights-2013-02-04>. Polity. Deepening Democracy through Access to Information.

Chakrabarty, D. (2000). Provincializing Europe: Postcolonial thought and historical difference. Princeton, NJ: Princeton University Press.

Chakravartty, P., Kuo, R., Grubbs, V., \& McIlwain, C. (2018). \#CommunicationSoWhite_<https:// dx.doi.org/10.1093/joc/jqy003>. Journal of Communication, 68(2), 254-266.

Chang, T.-K., \& Tai, Z. (2005). Mass communication research and the invisible college revisited: The changing landscape and emerging fronts in journalism-related studies_<https://dx.doi.org/ $\underline{10.1177 / 107769900508200312>}$. Journalism and Mass Communication Quarterly, 82(3), 672694.

Combs, S. C. (2005). The Dao of rhetoric. Albany, NY: SUNY Press. 
Connell, R. (2007). Southern theory: Social science and the global dynamics of knowledge. Cambridge, UK, and Malden, MA: Polity.

Curran, J., \& Park, M.-J. (2000). De-westernizing media studies. New York, NY: Routledge.

Dabashi, H. (2015). Can non-Europeans think? London, UK: Zed books.

Dajani. (2013). Pedagogic challenges facing development of media studies in Arab universities <https://ajouronline.com/index.php/AJHSS/article/view/11 >. Asian Journal of Humanities and Social Studies, 1(1).

Desai, M. K. (2017). Journalism education in India: Maze or mosaic? In R. S. Goodman \& E. Steyn (Eds.), Global journalism education in the 21st century: Challenges and innovations (pp. 113-136). Austin, TX: Knight Center for Journalism in the Americas.

Deuze, M. (2006). Global journalism education: A conceptual approach_<https://dx.doi.org/ 10.1080/14616700500450293>. Journalism Studies, 7(1), 19-34.

Dissanayake, W. (2007). Nagarjuna and modern communication theory. China Media Research, 3(4), 34-41.

Dissanayake, W. (2009). The production of Asian theories of communication: Contexts and challenges $\leq$ https://dx.doi.org/10.1080/01292980903293411>. Asian Journal of Communication, 19(4), 453-468.

Downing, J. D. H. (1996). Internationalizing media theory. Transition, power, culture: Reflections on media in Russia, Poland, and Hungary, 1980-95. London, UK: SAGE.

Dube, B., \& Rabe, L. (2017). Spaces of resistance in the de-westernization of journalism curricula narrative in post-1994 South Africa <https://dx.doi.org/10.1386/jams.9.3.415_1>. Journal of African Media Studies, 9(3), 415-433.

Enghel, F., \& Becerra, M. (2018). Here and there: (Re)situating Latin America in international communication theory/Aquí y allá: (Re)situando a América Latina en la teoría de la comunicación internacional/Aqui e lá: (Re)situando a América Latina na teoria da comunicação internacional <https://dx.doi.org/10.1093/ct/qty005>. Communication Theory, 28(2), 111-130.

Etzioni, A. (2003). A 308. Communitarianism. In K. Christensen \& D. Levinson (Eds.), Encyclopaedia of community: From the village to the virtual world (Vol. 1, A-D, pp. 224-228). Thousand Oaks, CA: SAGE.

Fanon, F. (1952). Black skin, white masks. New York, NY: Grove Press.

Faust, M. (2017). Bridging east and west: The dynamic paradox approach. Integrating Yin Yang and dynamic-transactional approaches. China Media Research, 13(3), 47-59.

Fourie, P. J. (2007). Moral philosophy as the foundation of normative media theory: The case of African Ubuntuism <https://dx.doi.org/10.1515/COMMUN.2007.001>.Communications, 32(1), $1-30$.

Frost, C. (2017). The United Kingdom juggles training and education: Squeezed between the newsroom and the classroom. In R. S. Goodman \& E. Steyn (Eds.), Global journalism education 
in the 21st century: Challenges and innovations (pp. 199-218). Austin, TX: Knight Center for Journalism in the Americas.

Früh, W., \& Schönbach, K. (2005). Der dynamisch-transaktionale Ansatz III: Eine Zwischenbilanz. Publizistik, 50(1), 4-20.

Glück, A. (2016). What makes a good journalist_<https://dx.doi.org/10.1080/1461670x. 2016.1175315>? Journalism Studies, 17(7), 1-11.

Glück, A. (2017). Journalistic practice of emotionality. A cross-cultural comparison of India and the United Kingdom <http://etheses.whiterose.ac.uk/20011/> (Doctoral dissertation). University of Leeds, Leeds, UK.

Goh, D. P. S. (2012). Oriental purity: Postcolonial discomfort and Asian values. positions: east asia cultures critique, 20(4), 1041-1066.

Golding, P. (1977). Media professionalism in the Third World: The transfer of an ideology. In J. Curran, M. Gurevitch, \& J. Woollacott (Eds.), Mass communication and society (pp. 291-308). London, UK: Edward Arnold.

Goodman, R. S. (2017a). Epilogue: Global journalism education moving forward. In R. S. Goodman \& E. Steyn (Eds.), Global journalism education in the 21st century: Challenges and innovations (pp. 449-455). Austin, TX: Knight Center for Journalism in the Americas.

Goodman, R. S. (2017b). Introduction: Global Journalism Education. In R. S. Goodman \& E. Steyn (Eds.), Global journalism education in the 21st century: Challenges and innovations (pp. 1-13). Austin, TX: Knight Center for Journalism in the Americas.

Gunaratne, S. A. (2005). The Dao of the press: A humanocentric theory. Cresskill, NJ: Hampton Press.

Gunaratne, S. A. (2009a). Emerging global divides in media and communication theory:

European universalism versus non-western reactions_<https://dx.doi.org/

10.1080/01292980903293247>. Asian Journal of Communication, 19(4), 366-383.

Gunaratne, S. A. (2009b). Globalization: A Non-western perspective: The bias of social science/ communication oligopoly <https://academic.oup.com/ccc/article-abstract/2/1/60/4067408>. Communication, Culture, and Critique, 2(1), 60-82.

Gunaratne, S. A. (2010). De-westernizing communication/social science research: Opportunities and limitations <https://dx.doi.org/10.1177/0163443709361159>. Media, Culture and Society, 32(3), 473-500.

Gunaratne, S. A. (2014). Blending east-west philosophies to meta-theorize mediatization and revise the news paradigm. In R. S. Fortner \& P. M. Fackler (Eds.), The handbook of media and mass communication theory (pp. 819-843). Chichester, UK: J. Wiley \& Sons.

Gunaratne, S. A. (2015). Globalizing communication/journalism, ending fragmentation within philosophy, and analyzing history as life spans in samsara_<https://dx.doi.org/

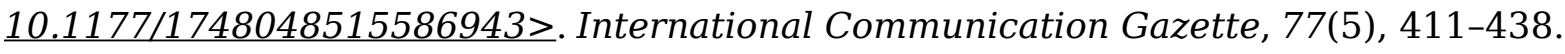


Hall, S. (1997). The local and the global: Globalization and ethnicity. In A. D. King (Ed.), Culture, globalization and the world-system. Contemporary conditions for the representation of identity. London, UK: Macmillan.

Hammami, S. (2005). Les sciences de l'information et da la communication dans le monde arabe: Réflexions sur les difficultés d'émergence d'une discipline. Revue Tunisienne de Communciation, 1(45), 7-42.

Harindranath, R. (2014). The view from the Global South: An introduction < $<$ ttps://dx.doi.org/ 10.1080/13688790.2014.966412>. Postcolonial Studies, 17(2), 109-114.

Harkins, S., \& Lugo-Ocando, J. (2016). Victorian discourses of poverty and race in modern journalism. In L. Matthews-Jones \& A. O’Neal (Eds.), Re-visioning the Victorians. London, UK: Palgrave MacMillan.

INFOCORE. (2017). (In)forming conflict prevention, response and resolution: The role of media in violent conflict_<https://www.globalgovernance.eu/work/projects/infocore-informing-conflictprevention-response-and-resolution-the-role-of-media-in-conflict/>. Global Governance Institute.

Jaber, J. M., \& Richter, C. (2014). From the field: Building on area studies expertise: The ArabEuropean Association for Media and Communication Researchers (AREACORE). Global Media Journal, 4(1), 1-6.

Jayyusi, L. (2007). Internationalizing media studies: A view from the Arab world_<https:// dx.doi.org/10.1177/17427665070030030102>. Global Media and Communication, 3(3), 251-255.

Jenco, L. (2013). Revisiting Asian values. Journal of the History of Ideas, 74(2), 237-258.

Kassab, E. S. (2013). Contemporary Arab thought: Cultural critique in comparative perspective. New York, NY: Columbia University Press.

Kim, M.-S. (2009). Cultural bias in communication science: Challenges of overcoming ethnocentric paradigms in Asia <https://dx.doi.org/10.1080/01292980903293338>. Asian Journal of Communication, 19(4), 412-421.

Kincaid, D. L. (1987). Communication theory: Eastern and western perspectives. San Diego, CA: Academic Press.

Klein, D. B., \& Chiang, E. (2004). The Social Science Citation Index: A black box-with an ideological bias? Econ Journal Watch, 1(1), 134-165.

Korkonosenko, S. G. (2015). Global de-Westernization trend in media studies and Russian journalism theory. Central European Journal of Communication, 8(2), 175-186.

Kuhn, T. (1962). The structure of scientific revolutions. Chicago, IL: University of Chicago Press.

Kuo, E. C. Y., \& Chew, H. E. (2009). Beyond ethnocentrism in communication theory: Towards a culture-centric approach <http://dx.doi.org/10.1080/01292980903293361>. Asian Journal of Communication, 19(4), 422-437.

Lamont, M. (2009). How professors think. Inside the curious world of academic judgment. Cambridge, MA: Harvard University Press. 
Levine, T. R., Park, H. S., \& Kim, R. K. (2007). Some conceptual and theoretical challenges for cross-cultural communication research in the 21st century_<https://dx.doi.org/

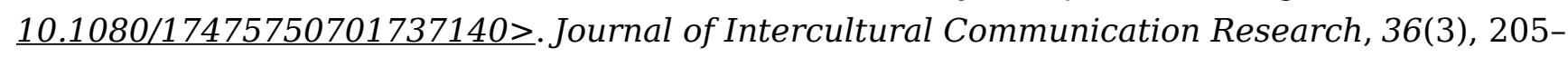
221.

Lo, K.-C. (2013). Rethinking Asianism and method< <https://dx.doi.org/ 10.1177/1367549413501480>. European Journal of Cultural Studies, 17(1), 31-43.

Loo, E. (2004). A Daoist perspective of normative media practice: Profile interview: Shelton Gunaratne. Asia Pacific Media Educator, 15, 213-220.

Ludden, D. (2002). A brief history of subalternity. In D. Ludden (Ed.), Reading subaltern studies. Critical history, contested meaning, and the globalisation of South Asia (pp. 1-39). Delhi, India: Permanent Black.

Lugo-Ocando, J., \& Glück, A. (2018). Worker's struggles, ideological struggle and the news: How national imaginary and anticommunism defined journalistic professionalism and identity in the West. Paper presented at the ICA 2018 Conference, May 26, Prague, Czech Republic.

Macfie, A. L. (2014). Introduction. In A. L. Macfie (Ed.), Orientalism: A reader (pp. 1-8). New York: New York University Press.

Madrid-Morales, D., \& Wasserman, H. (2018). Chinese media engagement in South Africa <https://dx.doi.org/10.1080/1461670x.2016.1266280>. Journalism Studies, 19(8), 12181235.

Martinisi, A., \& Lugo-Ocando, J. (2015). Overcoming the objectivity of the senses: Enhancing journalism practice through Eastern philosophies_<https://dx.doi.org/

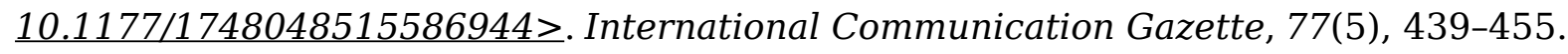

Masood, E. (2017). Science and Islam: A history. London, UK: Icon.

Mattison, C. (2012, May 2, 2012). Delinking, decoloniality and dewesternization: Interview with Walter Mignolo (Part II)_http://criticallegalthinking.com/2012/05/02/delinking-decolonialitydewesternization-interview-with-walter-mignolo-part-ii/>. Critical Legal Thinking: Law and the Political.

Maxwell, A. (2011). Introduction. Bridges and bulwarks: A historiographic overview of the EastWest discourses. In A. Maxwell (Ed.), The East-West discourse: Symbolic geography and its consequences (pp. 1-32). Bern, Switzerland: Peter Lang.

MeCoDEM. (2017). Media, conflict, and democratization $\leq h t t p: / / w w w . m e c o d e m . e u>$.

Mignolo, W. D. (2011). The darker side of Western modernity: Global futures, decolonial options. Durham, NC: Duke University Press.

Mohamed, A. (2006). Journalistic ethics and responsibility in relation to freedom of expression: An Islamic perspective. In S. J. A. Ward \& H. Wasserman (Eds.), Media ethics beyond borders: A global perspective (pp. 142-156). Johannesburg, South Africa: Heinemann.

Mowlana, H. (2007). Theoretical perspectives on Islam and communication. China Media Research, 3(4), 23-33. 
Murthy, C. S. H. N. (2012). Indian cinema as a model for de-westernizing media studies: A comparative study of Indian philosophical and Western cultural theories_<https://dx.doi.org/ 10.1177/1326365×13498167>. Asia Pacific Media Educator, 22(2), 197-215.

Mutsvairo, B. (Ed.). (2018). The Palgrave handbook of media and communication research in Africa. Cham, Switzerland: Palgrave Macmillan.

Mutsvairo, B., \& Karam, B. (2018). Perspectives on political communication in Africa: Cham, Switzerland: Palgrave Macmillan.

Ndlela, N. (2009). African media research in the era of globalization. Journal of African Media Studies, 1(1), 55-68.

Ngũgĩ wa Thiong'o. (1986). Decolonising the mind: The politics of language in African Literature. Heinemann Educational.

Nordenstreng, K., \& Thussu, D. K. (2015). Mapping BRICS media. Abingdon, UK: Routledge.

Nwosimiri, O. (2017). Do the works of the nationalist-ideological philosophers undermine Hume's and Kant's ideas about race <https://dx.doi.org/10.1177/2158244017700678>? SAGE Open, 7(1).

Quebral, N. C. (1975). Development communication: Readings in development communication. Los Baños, the Philippines: UPLB Department of Development Communication.

Rao, S. (2011). The "local" in global media ethics_<https://dx.doi.org/10.1080/1461670x. 2011.614818>. Journalism Studies, 12(6), 780-790.

Ray, T. (2012). To de-westernize, yes, but with a critical edge: A response to Gunaratne and others <https://dx.doi.org/10.1177/0163443711432414>. Media, Culture, and Society, 34(2), 238-249.

Ringer, F. (1992). Fields of knowledge: French academic culture in comparative perspective, 1890-1920. Cambridge, UK: Cambridge University Press

Said, E. (1978). Orientalism. London, UK: Penguin Books.

Semati, M. (2011). Communication, Culture, and the Essentialized Islam <https://dx.doi.org/ 10.1080/10510974.2011.540975>. Communication Studies, 62(1), 113-126.

Shoemaker, P. J., \& Reese, S. D. (2014). Mediating the message in the 21st century: A media sociological perspective. New York, NY: Routledge.

Shome, R. (2016). When postcolonial studies meets media studies < https://nca.tandfonline.com/ doi/abs/10.1080/15295036.2016.1183801\#.W658eBNKgWo>. Critical Studies in Media Communication, 33(3), 245-263.

Skjerdal, T. S. (2012). The three alternative journalisms of Africa <https://dx.doi.org/

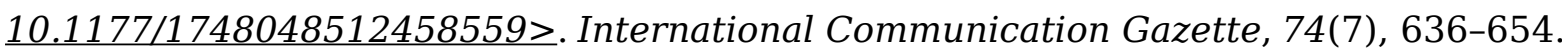

Takahashi, T. (2007). De-westernizing media studies: A Japanese perspective_<https://dx.doi.org/ 10.1177/17427665070030030403>. Global Media and Communication, 3(3), 330-335. 
Thussu, D. K. (2009). Internationalizing media studies. London, UK: Taylor \& Francis.

Tuchman, G. (1972). Objectivity as strategic ritual: An examination of newsmen's notions of objectivity <https://www.journals.uchicago.edu/doi/abs/10.1086/225193>. American Journal of Sociology, 77(4), 660-679.

Turner, B. S. (1994). Orientalism, Postmodernism, and Globalism. London, UK: Routledge.

Ugboajah, F. (1982). “Oramedia” or traditional media as effective communication options for rural development in Africa. Communicatio Socialis, 15(3), 211-221.

Ullah, M. S. (2014). De-westernization of media and journalism education in South Asia: In search of a new strategy. China Media Research, 10(2), 15-23.

Waisbord, S. (2015). De-westernization and cosmopolitan media studies. In C.-C. Lee (Ed.), Internationalizing "International Communication" (pp. 178-200). Ann Arbor: University of Michigan Press.

Waisbord, S., \& Mellado, C. (2014). De-westernizing communication studies: A reassessment $\leq$ https://dx.doi.org/10.1111/comt.12044>. Communication Theory, 24(4), 361372 .

Wang, G. (2011). De-westernizing communication research: Altering questions and changing frameworks. London, UK: Taylor \& Francis.

Wasserman, H. (2011). Global journalism studies: Beyond panoramas_<https://dx.doi.org/ 10.1080/02500167.2011.553823>. Communicatio, 37(1), 100-117.

Wasserman, H. (2018). Media, geopolitics, and power: A view from the global south. Springfield: University of Illinois Press.

Weischenberg, S. (1992). Journalistik: Theorie und Praxis aktueller Medienkommunikation. Band 1: Mediensystem, Medienethik, Medieninstitutionen. Opladen, Germany: Westdeutscher Verlag.

Wilkins, K. G. (2018, May). Special issue: Latin American communication theory today: Charting contemporary developments and their global relevance_<https://academic.oup.com/ct/issue/ 28/2>. Communication Theory, 28(2), 111-234.

Wiredu, K. (2001). Society and democracy in Africa. In T. Kiros (Ed.), Explorations in African political thought: Identity, community, ethics (pp. 171-184). New York, NY, and London, UK: Routledge.

\section{Notes}

1. This includes German ("De-Westernisierung”), French ("Desoccidendalisation”), Spanish ("Desoccidentalización”), Hindi (पाश्चात्यीकरण से नजित/ ग़ैर पश्चमीकरण exists rather theoretical than in language practice), Arabic, and Chinese. Russian's “девестернизация” арpears only on wiktionary.ru.

2. Originally, an Orientalism in the 18th or 19th century denoted either the study of the Arab world or of Asia, or referred to a style of art objects commonly associated with "Eastern" nations (Macfie, 2014). 
3. This association was formed through the initiative of the Free University of Berlin (FU Berlin) and the German Academic Exchange Service (DAAD).

4. The MeCoDEM (2017) project compares various countries of the Global South with a focus on traditional media actors and ICTs in conflicts accompanying political transitions from authoritarian rule to more democratic forms of government. INFOCORE (2017) analyzes the role of the media in conflicts and conflict prevention in Africa, the Middle East, and the Balkans.

\section{Related Articles}

Stuart Hall and Communication Studies

Cultural Studies and Communication

Media and Democracy From A European Perspective

Indigenous Languages: Their Threatened Extinction is a Global Responsibility

Gayatri Chakravarty Spivak: Relevance for Communication Studies

Paulo Freire and Communication Studies

Arjun Appadurai and Critical Cultural Studies

A Fanonian Philosophy of Race

Homi Bhabha and Communication Studies

Colonialism and Postcolonialism

Decolonization and Collaborative Media: A Latin American Perspective

Ranajit Guha's Historiography of Colonial India

Nation, Identity, and Power in the Critical Cultural Studies Tradition

Development Journalism

Ethnicity, Race, and Journalism

Reading "Asian Values" into Journalism Practices in Asia

Postcolonial Approaches to Communication and Culture

Rhetorical Contexts of Colonization and Decolonization

Pacific Media

Latin America and Critical Cultural Studies 